\title{
DIMENSI-DIMENSI KUALITAS LAYANAN: PENGUJIAN MODEL KUALITAS LAYANAN DARI PERSPEKTIF EUROPA
}

\author{
Chandra Kuswoyo \\ Rully Arlan Tjahyadi
}

Program Studi Manajemen Fakultas Ekonomi UK.Maranatha

Email: chandrakuswoyo@yahoo.com; rully_arlan@yahoo.com

Submitted: Jun 12, 2017; Reviewed: Jun 12, 2017; Accepted: Aug 19, 2017

\begin{abstract}
The purpose of this paper was to examine the role of functional quality, technical quality, and corporate image on customer satisfaction. Individual-level analyses from a sample of 265 students of Management study at Economic Faculty of Maranatha Christian University indicate that functional quality and corporate image are positively and significantly associated with customer satisfaction. Research findings indicate that functional quality and corporate image were found to be more important than technical quality in determining customer attitude.
\end{abstract}

Keywords: Functional Quality, Technical Quality, Corporate Image, Customer Satisfaction

\section{PENDAHULUAN}

Wacana strategi bersaing juga telah menjadi topik sentral bagi perguruan tinggi dalam menghadapi lingkungan kompetitif modern. Dalam lingkungan kompetitif yang modern, kepuasan pelanggan sangat bergantung dari kualitas layanan perusahaan (Rahman, M. S., Khan, A. H., \& Haque, M. M., 2012). Dalam industri pendidikan, kepuasan pelanggan dan kualitas layanan merupakan dipandang sebagai konsep penting bagi kesuksesan perguruan tinggi (Vatta \& Bhatara, 2013). Sehingga Penting bagi perguruan tinggi untuk memfokuskan pada kualitas pembelajaran dan kepuasan mahasiswa sebagai dua topik sentral dalam wacana strategi bersaing. Strategi bersaing yang perlu dikembangkan adalah memosisikan perguruan tinggi sebagai industri penyedia jasa (service provider industry), yaitu penyedia jasa yang memberikan layanan (service) yang sesuai dengan kebutuhan, keinginan, dan ekspektasi pelanggan (customer-oriented).

Sebagian besar studi kualitas layanan banyak memfokuskan pada pengukuran kualitas layanan dengan menggunakan instrumen SERVQUAL (tangibility, reliability, responsiveness, assurance, dan empathy) yang dikembangkan oleh Parasuraman et al. (1985,
1988) Banwet dan Datta (2003), serta Kang dan James (2004) telah mengkritik model tersebut yang mana instrumen SERVQUAL hanya memfokuskan pada functional quality, yaitu penilaian terhadap kualitas layanan hanya didasarkan pada proses bagaimana suatu jasa diberikan (service-delivery process). Evaluasi kualitas seharusnya tidak hanya didasarkan pada bagaimana jasa itu diberikan, tapi juga apa yang secara aktual pelanggan terima dari suatu jasa (technical quality).

Pemahaman mengenai sifat dasar dan dimensi-dimensi kualitas layanan masih belum ada kesepakatan (Brady \& Cronin, 2001). Hal ini memunculkan dua perspektif yang berbeda mengenai kualitas jasa, yaitu perspektif Amerika dan Europa. Perspektif Amerika didasarkan pada proposisi yang ditawarkan Parasuraman et al. (1985) yang memaparkan bahwa kualitas layanan dievaluasi berdasarkan atas dimensi kualitas fungsional-bagaimana suatu jasa disampaikan. Perspektif Europa menjelaskan kualitas layanan tidak hanya difokuskan pada dimensi kualitas fungsional tapi juga didasarkan pada kualitas teknis dan citra korporat. Dimensidimensi kualitas layanan dari perspektif Europa telah memberikan banyak pengaruh pada studi kualitas layanan (Ganesh \& Haslinda, 2014; 
Kang \& James, 2004; Rahman, Khan \& Haque, 2012).

Aspek teknis kualitas layanan didefinisikan sebagai persepsi pelanggan atas apa yang diterima sebagai hasil dari proses jasa atau apa yang secara aktual pelanggan terima dari suatu layanan (Grönroos, 1984b; Ganesh \& Haslinda, 2014; Kang \& James, 2004; Kang, 2006; Rahman, Khan \& Haque, 2012). Aspek fungsional kualitas layanan didefinisikan sebagai cara-cara suatu layanan diberikan kepada pelanggan (Grönroos, 1984b; Ganesh \& Haslinda, 2014; Kang \& James, 2004; Kang, 2006; Rahman, Khan \& Haque, 2012). Aspek ketiga yang juga penting dalam memberikan pengalaman kualitas layanan adalah citra korporat (Andreassen \& Lindestad, 1998; Ganesh \& Haslinda, 2014; Rahman, Khan \& Haque, 2012). Citra (image) didasarkan pada pemikiran bahwa pelanggan membawa pengalaman awal mereka dan keseluruhan persepsi terhadap perusahaan jasa dalam setiap interaksi.

Berdasarkan pada uraian yang telah dikemukakan sebelumnya, studi ini akan menguji secara empiris model SERVQUAL dari perspektif Europa pada kepuasan pelanggan. Penelitian ini memfokuskan pada setting perguruan tinggi dalam menguji model tersebut, secara khusus persepsi mahasiswa/i jurusan manajemen Fakultas Ekonomi Universitas Kristen Marantaha (FE UKM) terhadap kualitas layanan FE UKM dan citra UKM di benak mereka. Studi ini diharapkan dapat memberikan masukan bagi pengelola untuk memfokuskan tidak hanya pada aspek fungsional melainkan pada aspek teknis dan membangun citra UKM di mata pelanggan.

\section{KERANGKA TEORITIS Pengertian Jasa}

Jasa juga didefinisikan sebagai tindakan atau perfoma yang ditawarkan oleh satu kelompok kepada kelompok lainnya, yang pada dasarnya tidak berwujud dan tidak menghasilkan kepemilikan apapun (Kotler \& Keller, 2012). Dalam pemasaran jasa, kepuasan pelanggan melalui penyampaian kualitas layanan merupakan konsep yang sangat penting (Ganesh \& Haslinda, 2014). Pemahaman mengenai jasa sangat penting sebagai upaya menciptakan kepuasan pelanggan. Lovelock (1983), dalam Lovelock dan Writz (2007) telah mengembangkan suatu skema klasifikasi jasa yang berguna dalam mengidentifikasi isu dan 72 peluang pemasaran yang kemudian akan memengaruhi sifat dasar tugas pemasaran dalam menentukan keahlian-keahlian yang diperlukan dalam menyampaikan jasa yang berkualitas (delivery service quality) kepada pelanggan, yang meliputi: people processing, possession processing, mental stimulus processing, dan information processing.

\section{Kualitas}

Kualitas merupakan satu dari banyak konsep dalam ilmu sosial yang sulit untuk didefinisikan. Garvin (1988) dalam Lagrosen et al., (2004) telah mengklasifikasikan kualitas ke dalam lima kategori utama:

a. Transcedent. Kualitas merupakan ukuran subjektif dan personal. Konsep kualitas disini terkait dengan keindahan (beauty).

b. Product-based. Kualitas dipahami sebagai variabel yang dapat diukur. Dasar pengukurannya adalah atribut-atribut objektif suatu produk.

c. User-based. Kualitas dipahami sebagai memuaskan kebutuhan konsumen. Definisi kualitas disini difokuskan pada eksternal.

d. Manufacturing-based. Kualitas difokuskan pada internal. Kualitas disini didefinisikan sebagai kesesuaian antara tuntutan dan spesifikasi.

e. Value-based. Kualitas terkait dengan cost atau memenuhi ekspektasi pelanggan terkait dengan kualitas, harga, dan ketersediaan.

\section{Kualitas Layanan (Service Quality)}

Konstruk kualitas layanan yang dikonseptualisakan dalam literatur pemasaran jasa memfokuskan pada kualitas yang dipersepsikan (perceived quality), yang merupakan suatu bentuk sikap yang berasal dari suatu perbandingan ekspektasi dengan persepsi dari suatu performa (Kang, 2006). Kualitas layanan merupakan kesenjangan antara level jasa yang diharapkan dan persepsi konsumen terhadap level jasa yang akan diterima SERVQUAL mengidentifikasi (Parasuraman et al., 1988).

Instrumen SERVQUAL yang dikembangkan oleh Parasuraman yang meliputi tangibility, reliability, responsiveness, assurance, dan empathy tersebut lebih memfokuskan pada kualitas fungsional, yaitu bagaimana suatu jasa diberikan (service-delivery process). Evaluasi jasa tidak hanya difokuskan pada kualitas fungsional, tapi juga mencakup kualitas teknik (Ganesh \& Haslinda, 2014; Rahman, Khan \& 
Haque, 2012) dan citra korporat (Ganesh \& Haslinda, 2014; Grönroos, 1984b; Rahman, Khan \& Haque, 2012).

\section{Evolusi Kualitas Layanan}

Kualitas layanan diakui memiliki banyak dimensi (Berry et al., 1985; Grönroos, 1984b; Parasuraman et al., 1985). Diskusi kontemporer pada dimensi-dimensi kualitas layanan telah diprakarsai oleh perspektif Europa yang telah memberikan banyak pengaruh pada studi dimensi kualitas layanan (Kang \& James, 2004). Berkut ini akan dipaparkan mengenai dimensidimensi kualitas layanan dari perspektif Europa.

Rahman, Khan dan Haque (2012) mendefinisikan kualitas layanan berkaitan dengan kualitas fisik (physical quality), kualitas interaktif (interactive quality), dan citra korporat (corporate image). Kualitas fisik berkaitan dengan aspek tangible dari jasa. Kualitas interaktif berkaitan dengan interaksi dua arah antara pelanggan dan penyedia jasa (service provider). Citra korporat atau kualitas korporat berkenaan dengan citra yang dihubungkan dengan penyedia jasa oleh pelanggan saat ini dan pelanggan potensial. Kualitas korporat cenderung lebih stabil sepanjang waku dibandingkan dengan dua dimensi kualitas layanan lainnya (Kang \& James, 2004).

Grönroos (1982), dalam Kang (2006) mengidentifikasi dua dimensi kualitas layanan lainnya yaitu aspek teknis (technical aspect) dan aspek fungsional (functional aspect). Kualitas teknis ("what" service is provided) berkaitan dengan apa yang secara aktual pelanggan terima dari suatu layanan atau service encounter. Dimensi ini berhubungan dengan hasil dari suatu layanan (service outcome). Kualitas fungsional fokus pada bagaimana suatu layanan disampaikan pada pelanggan yaitu persepsi pelanggan terhadap interaksi yang terjadi selama penyampain jasa (service delivery). Dimensi ini berkaitan dengan proses suatu layanan (service process). Grönroos (1984b) menambahkan pentingnya citra korporat dalam memberikan pengalaman kualitas layanan.

Para ahli dari perspektif Europa memandang kualitas layanan tidak hanya bergantung pada evaluasi dari proses penyampaian jasa, melainkan evaluasi dari hasil jasa itu sendiri. Pandangan ini berbeda dengan pandangan Amerika mengenai kualitas layanan. Menurut perspektif Amerika, evaluasi kualitas tidak hanya dibuat semata-mata oleh hasil dari suatu jasa, melainkan evaluasi terhadap proses penyampaian jasa (service-delivery process). Perspektif Amerika didasarkan pada proposisi yang ditawarkan oleh Parasuraman et al. (1985) yang memaparkan bahwa kualitas layanan dievaluasi berdasarkan atas dimensi kualitas fungsional bagaimana suatu jasa disampaikan.

Swartz dan Brown (1989) berupaya untuk menyimpulkan dimensi-dimensi kualitas layanan berdasarkan pada studi-studi sebelumnya dan mereka mengkategorikan dimensi-dimensi kualitas layanan ke dalam dua kategori, yaitu "what" (evaluasi setelah performa) dan "how" (evaluasi selama performa). Gambar 1 akan menunjukkan kategorisasi dimensi-dimensi kualitas layanan berdasarkan pada dimensidimensi kualitas layanan yang diusulkan oleh beberapa ahli.

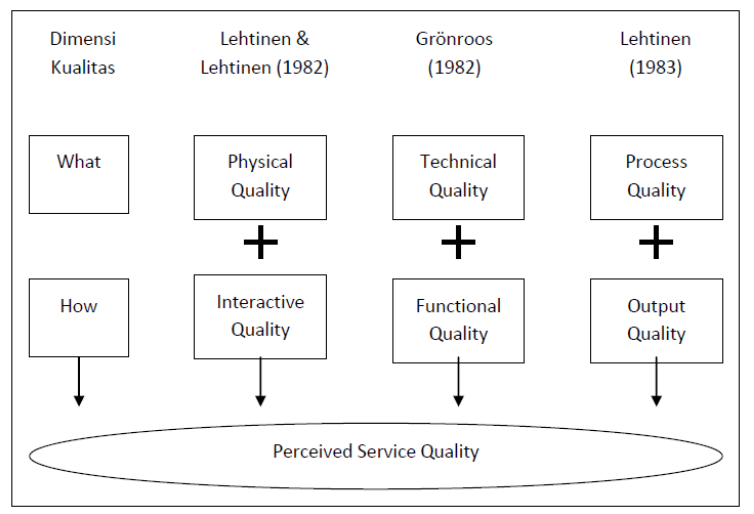

Gambar 1 Dimensi-Dimensi Kualitas Layanan

Berdasarkan pada penjelasan mengenai dimensi-dimensi kualitas layanan yang telah dikemukakan sebelumnya, penelitian ini akan memfokuskan pada dimensi kualitas layanan yang dikembangkan oleh Grönroos sebagai determinan perceived service quality. Kualitas teknik berkaitan dengan hasil aktual dari suatu layanan. Kualitas fungsional berkenaan dengan interaksi pelanggan dengan pe-nyedia jasa. Elemen penting lainnya dalam kualitas layanan adalah citra korporat. Citra korporat didefinisikan sebagai persepsi pelanggan terhadap organisasi jasa. Sebagaimana yang telah dijelaskan sebelumnya, pelanggan membawa pengala-man awal mereka dan keseluruhan persepsi terhadap perusahaan jasa dalam setiap interaksi. Oleh karena itu citra korporat merupakan elemen penting lainnya bagi keseluruhan evaluasi jasa (Gönroos, 1984b).

Penelitian ini akan memfokuskan pada setting peruguruan tinggi, secara khusus pada Fakultas Ekonomi Universitas Kristen Maranatha, Bandung. Dalam konteks penelitian ini, kualitas teknik berkaitan dengan tingkat 
keahlian yang diperoleh selama proses pembelajaran dan umpan balik atas kinerja mahasiswa. Kualitas fungsional berkenaan dengan proses penyampaian layanan kepada mahasiswa dengan menggunakan model SERVQUAL yang dikembangkan oleh Parasuraman et al. (1985) dan citra korporat berkaitan dengan keseluruhan persepsi mahasiswa terhadap Universitas Kristen Maranatha.

Model kualitas layanan pada penelitian ini difokuskan pada tiga dimensi kualitas layanan yang dikembangkan oleh Grönroos, yaitu technical quality, functional quality, dan corporat image. Menurut model tersebut, total kualitas layanan (the total quality of a service) merupakan fungsi dari technical quality, functional quality, dan corporat image (Grönroos, 1984a). Gambar 2 menunjukkan model kualitas layanan Grönroos.

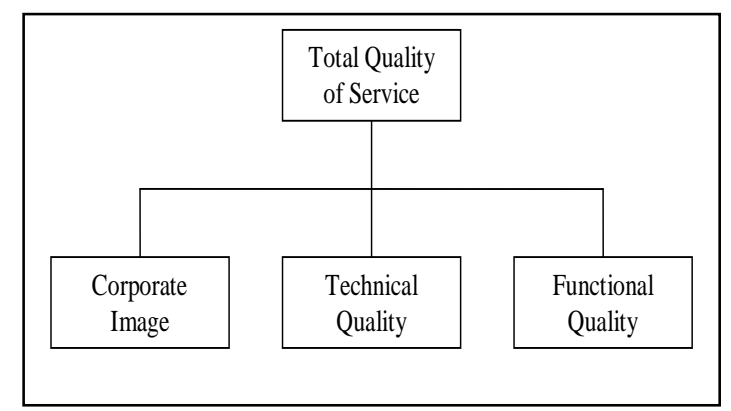

Gambar 2 Model Kualitas Layanan Grönroos

Kepuasan Pelanggan (Customer Satisfaction)

Kepuasan pelanggan merupakan konsep penting yang digunakan sebagai alat dalam membantu menciptakan keunggulan bersaing (competitive advantage) dan loyalitas pelanggan. Jika performa suatu entitas berada di bawah ekspektasinya, maka pelanggan tidak puas terhadap entitas tersebut. Sebaliknya, pelanggan akan puas, jika performa suatu entitas memenuhi atau melampaui ekspektasi yang telah dibentuknya.

Pada penelitian ini mahasiswa merupakan pelanggan utama. Ketika mahasiswa diperlakukan sebagai pelanggan utama dalam konteks institusi pendidikan, maka institusi pendidikan harus memfokuskan pada edukasi berorientasi pada pelanggan (customer-oriented education) (Gold, 2001, dalam Banwet \& Datta, 2003).
Pengembangan Hipotesis

Pengaruh Functional Quality pada Kepuasan Pelanggan

Banwet dan Datta (2003) menemukan bahwa kualitas layanan fungsional berpengaruh positif signikan pada kepuasan mahasiswa. Sesuai dengan temuan Kang dan James (2004), service quality perception (fungtional quality dan technical quality) berpengaruh positif signifikan pada kepuasan pelanggan. Berdasarkan pada uraian dan hasil temuan penelitian sebelumnya, hipotesis yang diusulkan pada penelitian ini adalah:

$\mathbf{H}_{\mathbf{1}}$ : Functional quality akan berpengaruh positif pada kepuasan pelanggan.

\section{Pengaruh Technical Quality pada Kepuasan Pelanggan}

Hasil temuan Kang dan James (2004) menunjukkan bahwa technical quality berpengaruh positif signifikan pada kepuasan pelanggan. Berdasarkan pada uraian dan hasil temuan penelitian sebelumnya, hipotesis yang diusulkan pada penelitian ini adalah:

$\mathbf{H}_{2}$ : Tehcnical quality akan berpengaruh positif pada kepuasan pelanggan.

\section{Pengaruh Corporate Image pada Kepuasan Pelanggan}

Andreassen dan Lindestad (1998) menemukan bahwa citra korporat berpengaruh positif signifikan pada kepuasan pelanggan. Berdasarkan pada uraian dan hasil temuan penelitian sebelumnya, hipotesis yang diusulkan pada penelitian ini adalah:

$\mathbf{H}_{2}$ : Corporate Image akan berpengaruh positif pada kepuasan pelanggan.

\section{Model Penelitian}

Model yang ditawarkan pada penelitian ini dapat ditunjukkan pada Gambar 3.

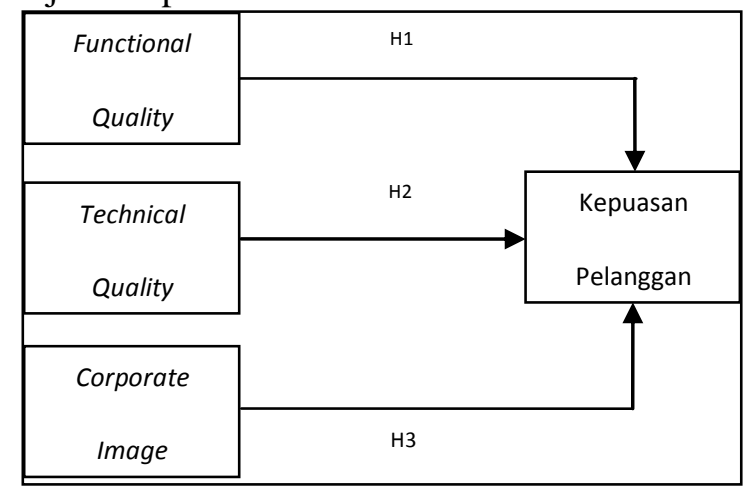

Gambar 3 Rerangka Model Dasar dan Path yang Dihipotesiskan 


\section{Metode Penelitian}

$\mathrm{Bab}$ ini membahas mengenai metode penelitian yang meliputi objek dan subjek penelitian, teknik pengumpulan data, definisi operasional dan skala pengukuran, pengujian outliers, pengujian instrumen penelitian yang berupa uji validitas dan reliabilitas, serta statistik deskriptif dan korelasi antar-konstruk. Metoda analisis data yang digunakan dalam penelitian ini adalah regresi majemuk (multiple regreesion) dengan bantuan software SPSS 11.5 for windows.

\section{Objek dan Subjek Penelitian}

Sampel penelitian adalah para mahasiswa/i FE UKM dengan kriteria mahasiswa/i angkatan 2005-2008 pada program studi Manajemen dan Akuntansi. Hal ini disebabkan karena mahasiswa/i tersebut telah mempunyai cukup pengalaman berkaitan dengan berbagai bentuk layanan yang diberikan oleh FE UKM baik akademik maupun non-akademik. Jumlah sampel dalam penelitian ini ditentukan berdasarkan 5-10 kali jumlah variabel (Malhotra, 1996, dalam Giantari et al., 2008). Jumlah butir dalam penelitian ini adalah sebanyak 36 butir. Jumlah sampel pada penelitian ini adalah 265 mahasiswa/i. Ukuran sampel untuk setiap angkatan akan diambil secara proposional.

\section{Definisi Operasional dan Skala Pengukuran}

Definisi operasional variabel dan skala pengukuran yang digunakan dalam penelitian ini ditunjukkan pada Tabel 1 berikut.

\section{Pengujian Outliers}

Outliers adalah observasi yang muncul dengan nilai-nilai ekstrim yang me-miliki karakteristik unik yang sangat berbeda dari observasi lainnya dan muncul dalam bentuk nilai ekstrim baik untuk variabel tunggal maupun variabel kombinasi (Hair et al., 1998). Dalam analisis multivariate, outliers dapat dievaluasi berdasar nilai Mahalanobis distance dengan nilai degree of freedom sejumlah indikator yang digunakan dalam penelitian pada tingkat $p<0,001$. Uji ouliers dilakukan dengan menggunakan aplikasi AMOS 5.0.

\section{Pengujian Validitas dan Reliabilitas}

Peneliti melakukan construct validity untuk menguji tingkat validitas. Pengujian validitas dilakukan melalui faktor analisis dengan menggunakan factor loading. Kriteria terhadap signifikansi factor loading adalah factor loading
$>0,3$ adalah signifikan, factor loading > 0,4 lebih signifikan, dan factor loading $>0,5$ adalah sangat signifikan.

Uji reliabilitas digunakan untuk mengetahui tingkat konsistensi terhadap instrumen-instrumen yang mengukur konsep dan membantu untuk mengetahui kebaikan alat ukur. Konsistensi internal butir-butir pernyataan dalam kuesioner akan diuji dengan menggunakan Cronbach's Alpha. Nilai rule of thumb yang akan digunakan dalam Cronbach's Alpha adalah harus lebih besar dari 0,7, meskipun nilai 0,6 juga masih dapat diterima (Hair et al., 1998).

Tabel 1 Definisi Operasional dan Skala Pengukuran

\begin{tabular}{|c|c|c|c|}
\hline Varibel & Definisi & Indikator & Skala \\
\hline $\begin{array}{l}\text { Functional } \\
\text { Quality }\end{array}$ & $\begin{array}{lr}\text { Persepsi pelanggan } \\
\text { terhadap interaksi yang } \\
\text { terjadi selama } \\
\text { penyampaian jasa } \\
\text { (Grönroos, 1984b). }\end{array}$ & $\begin{array}{l}\text { - Tangible Aspect } \\
\text { - Empathy } \\
\text { - Responsiveness } \\
\text { - Reliablity } \\
\text { - Assurance }\end{array}$ & $\begin{array}{l}\text { Likert } \\
\text { Scale }\end{array}$ \\
\hline $\begin{array}{l}\text { Technical } \\
\text { Quality }\end{array}$ & $\begin{array}{l}\text { Apa yang secara aktual } \\
\text { pelanggan terima dari } \\
\text { suatu layanan } \\
\text { (Grönroos, 1984b). }\end{array}$ & $\begin{array}{l}\text { - The Extent of Shill } \\
\text { - Feedback on Student } \\
\text { Performance }\end{array}$ & $\begin{array}{l}\text { Likert } \\
\text { Scale }\end{array}$ \\
\hline $\begin{array}{l}\text { Corporate } \\
\text { Image }\end{array}$ & $\begin{array}{l}\text { Citra yang dihubungkan } \\
\text { dengan penyedia jasa } \\
\text { oleh pelanggan saat ini } \\
\text { dan pelanggan potensial } \\
\text { (Kang \& James, 2004). }\end{array}$ & $\begin{array}{l}\text { - Reliable University } \\
\text { - Excellence Service } \\
\text { - Contribution to the } \\
\text { Society } \\
\text { - Good Reputation } \\
\text { - Large-scale } \\
\text { University } \\
\text { - Familiar to the } \\
\text { Customer } \\
\text { - Honest }\end{array}$ & $\begin{array}{l}\text { Likert } \\
\text { Scale }\end{array}$ \\
\hline $\begin{array}{l}\text { Customer } \\
\text { Satisfaction }\end{array}$ & $\begin{array}{l}\text { Hasil evaluasi subjektif } \\
\text { pelanggan bahwa } \\
\text { penyedia jasa yang } \\
\text { dipilih memenuhi atau } \\
\text { melampaui } \\
\text { ekspektasinya. (Kang \& } \\
\text { James, 2004). }\end{array}$ & $\begin{array}{l}\text { - Satisfied with my } \\
\text { decision } \\
\text { - My Choice was a } \\
\text { wise one } \\
\text { - Happy to Use this } \\
\text { service } \\
\text { - Good Experience }\end{array}$ & $\begin{array}{c}\text { Likert } \\
\text { Scale }\end{array}$ \\
\hline
\end{tabular}

\section{Metoda Analisis Data}

Analisis yang digunakan dalam penelitian ini adalah multiple regression (regresi berganda/majemuk) dengan menggunakan bantuan software SPSS 11.5 for Windows. Analisis statistik ini digunakan untuk menguji pengaruh variabel independen pada variabel dependen yang mana jumlah variabel independen yang diuji lebih dari satu variabel. Dalam penelitian ini, terdapat 3 (tiga) variabel independen, yaitu functional quality, technical quality, dan corporate image.

\section{HASIL DAN PEMBAHASAN}

Jumlah kuesioner pada penelitian ini adalah sebanyak 265 kuesioner. Jumlah tersebut layak untuk diuji karena telah memenuhi ukuran minimum sampel yang dianjurkan, yaitu sebanyak 100 sampel atau minimum melampaui 5 kali jumlah parameter yang diestimasi. 
Gambaran karakteristik responden pada penelitian ini dapat dilihat di Tabel 2 dan 3 di bawah ini.

Tabel 2 Karakteristik Responden Berdasarkan Jenis Kelamin

\begin{tabular}{cccc}
\hline No & $\begin{array}{c}\text { Jenis } \\
\text { Kelamin }\end{array}$ & Jumlah & Persentase \\
\hline 1 & Laki-Laki & 113 & $42,6 \%$ \\
2 & Perempuan & 152 & $57,4 \%$ \\
Total & & 265 & $100 \%$ \\
\hline
\end{tabular}

Tabel 3 Karakteristik Responden Berdasarkan Angkatan

\begin{tabular}{cccc}
\hline No & Angkatan & Jumlah & Persentase \\
\hline 1 & 2005 & 47 & $17,7 \%$ \\
2 & 2006 & 57 & $21,5 \%$ \\
3 & 2007 & 78 & $29,4 \%$ \\
4 & 2008 & 83 & $31,3 \%$ \\
Total & & 265 & $100 \%$ \\
\hline
\end{tabular}

Sumber: Hasil Pengolahan Data

\section{Hasil Pengujian Outliers}

Dalam penelitian ini, jumlah indikator yang digunakan adalah sebanyak 36 item. Dengan demikian, apabila terdapat nilai Mahalanobis distance yang lebih besar dari $\chi^{2}(36,0,001)=$ 59,703 , maka nilai tersebut adalah outliers multivariate.

Berdasarkan kriteria nilai Mahalanobis distance, dari 265 data terdapat 26 data observasi yang dianggap sebagai outliers jumlah sampel yang digunakan untuk analisis lebih lanjut adalah 239 sampel.

\section{Hasil Pengujian Validitas}

Pengujian validitas dilakukan melalui faktor analisis dengan menggunakan factor loading. Indikator setiap konstruk yang memiliki factor loading signifikan menunjukkan satu kesatuan alat ukur yang mengukur konstruk yang sama dan dapat memrediksi dengan baik konstruk yang seharusnya diprediksi.

Tabel 4 menunjukkan bahwa terdapat 8 instrumen yang dinyatakan tidak valid pada loading factor 0,4 , yaitu item pertama dan kedua dari konstruk functional quality, item pertama dari konstruk technical quality, item pertama dan kelima dari konstruk corporate image, serta pertama sampai dengan ketiga dari konstruk customer satisfaction. Tabel 5 akan ditunjukkan hasil pengujian validitas akhir.
Tabel 4 Analisis Faktor (Awal)

\begin{tabular}{|c|c|c|c|c|c|}
\hline \multirow[t]{2}{*}{ Item } & \multicolumn{4}{|c|}{ Komponen } & \multirow[t]{2}{*}{ Keterangan } \\
\hline & 1 & 2 & 3 & 4 & \\
\hline FQ1 & 0.648 & & 0.455 & & Tidak valid \\
\hline $\mathrm{FQ} 2$ & 0.699 & & 0.565 & & Tidak valid \\
\hline FQ3 & 0.788 & & & & Valid \\
\hline FQ4 & 0.768 & & & & Valid \\
\hline FQ5 & 0.758 & & & & Valid \\
\hline FQ6 & 0.737 & & & & Valid \\
\hline FQ7 & 0.748 & & & & Valid \\
\hline FQ8 & 0.745 & & & & Valid \\
\hline FQ9 & 0.739 & & & & Valid \\
\hline FQ10 & 0.739 & & & & Valid \\
\hline FQ11 & 0.738 & & & & Valid \\
\hline FQ12 & 0.655 & & & & Valid \\
\hline FQ13 & 0.700 & & & & Valid \\
\hline FQ14 & 0.699 & & & & Valid \\
\hline FQ15 & 0.713 & & & & Valid \\
\hline FQ16 & 0.770 & & & & Valid \\
\hline FQ17 & 0.733 & & & & Valid \\
\hline FQ18 & 0.693 & & & & Valid \\
\hline FQ19 & 0.734 & & & & Valid \\
\hline FQ20 & 0.754 & & & & Valid \\
\hline FQ21 & 0.707 & & & & Valid \\
\hline FQ22 & 0.697 & & & & Valid \\
\hline TQ23 & 0.425 & 0.633 & & & Valid \\
\hline TQ24 & & 0.767 & & & Tidak Valid \\
\hline TQ25 & & 0.760 & & & Valid \\
\hline TQ26 & & 0.732 & & & Valid \\
\hline TQ27 & & 0.799 & & & Valid \\
\hline $\mathrm{CI} 28$ & & 0.468 & 0.587 & & Tidak Valid \\
\hline CI29 & & & 0.693 & & Valid \\
\hline CI30 & & & 0.614 & & Valid \\
\hline CI31 & & & 0.597 & & Valid \\
\hline CI32 & & & 0.605 & 0.414 & Tidak Valid \\
\hline CS33 & & & 0.566 & 0.458 & Tidak Valid \\
\hline CS34 & 0.443 & & & 0.690 & Tidak Valid \\
\hline CS35 & 0.437 & & & 0.741 & Tidak Valid \\
\hline CS36 & & & & 0.665 & Valid \\
\hline
\end{tabular}

Sumber: Hasil Pengolahan Data

Berdasarkan pada tabel 4, item pertama dari konstruk customer satisfaction dieliminasi pada factor loading 0,577. Hasil pengujian ini menunjukkan bahwa sebanyak 35 item layak untuk dilakukan analisis lebih lanjut.

\section{Hasil Pengujian Reliabilitas}

Koefisien internal item-item pernyataan akan diuji dengan menggunakan koefisien Cronbach Alpha. Nilai rule of thumb yang akan digunakan dalam koefisien Cronbach Alpha adalah $\geq 0,7$, meskipun nilai 0,6 juga masih dapat diterima (Hair et al., 1998). Tabel 6 menunjukkan hasil pengujian reliabilitas pada penelitian ini. 
Tabel 5 Analisis Faktor (Akhir)

\begin{tabular}{|c|c|c|c|c|c|}
\hline \multirow[t]{2}{*}{ Item } & \multicolumn{4}{|c|}{ Komponen } & \multirow[t]{2}{*}{ Keterangan } \\
\hline & 1 & 2 & 3 & 4 & \\
\hline FQ1 & 0.641 & & & & Valid \\
\hline FQ2 & 0.692 & & & & Valid \\
\hline FQ3 & 0.780 & & & & Valid \\
\hline FQ4 & 0.776 & & & & Valid \\
\hline FQ5 & 0.755 & & & & Valid \\
\hline FQ6 & 0.734 & & & & Valid \\
\hline FQ7 & 0.751 & & & & Valid \\
\hline FQ8 & 0.743 & & & & Valid \\
\hline FQ9 & 0.743 & & & & Valid \\
\hline FQ10 & 0.745 & & & & Valid \\
\hline FQ11 & 0.729 & & & & Valid \\
\hline FQ12 & 0.653 & & & & Valid \\
\hline FQ13 & 0.709 & & & & Valid \\
\hline FQ14 & 0.704 & & & & Valid \\
\hline FQ15 & 0.723 & & & & Valid \\
\hline FQ16 & 0.767 & & & & Valid \\
\hline FQ17 & 0.726 & & & & Valid \\
\hline FQ18 & 0.697 & & & & Valid \\
\hline FQ19 & 0.738 & & & & Valid \\
\hline FQ20 & 0.752 & & & & Valid \\
\hline FQ21 & 0.699 & & & & Valid \\
\hline FQ22 & 0.690 & & & & Valid \\
\hline TQ23 & & 0.633 & & & Valid \\
\hline TQ24 & & 0.773 & & & Valid \\
\hline TQ25 & & 0.758 & & & Valid \\
\hline TQ26 & & 0.740 & & & Valid \\
\hline TQ27 & & 0.808 & & & Valid \\
\hline CI28 & & & 0.591 & & Valid \\
\hline CI29 & & & 0.680 & & Valid \\
\hline CI30 & & & 0.602 & & Valid \\
\hline CI31 & & & 0.592 & & Valid \\
\hline CI32 & & & 0.578 & & Valid \\
\hline CS33 & & & 0.566 & & Valid \\
\hline CS34 & & & & 0.683 & Valid \\
\hline CS35 & & & & 0.753 & Valid \\
\hline CS36 & & & & 0.698 & Valid \\
\hline
\end{tabular}

Sumber: Hasil Pengolahan

Tabel 6 Pengujian Reliabilitas

\begin{tabular}{ccc}
\hline Konstruk & $\begin{array}{c}\text { Koefisien } \\
\text { Cronbach } \\
\text { Alpha }\end{array}$ & Keterangan \\
\hline Functional Quality & 0.9830 & Reliabel \\
Tehnical Quality & 0.9116 & Reliabel \\
Corporate Image & 0.9157 & Reliabel \\
Customer & 0.8857 & Reliabel \\
Satisfaction & & \\
\hline Sumber: Hasil Pengolahan &
\end{tabular}

Sumber: Hasil Pengolahan

Tabel 6 menunjukkan bahwa seluruh konstruk penelitian memiliki nilai Cronbach Alpha di atas 0,8 . Hasil tersebut menunjukkan hasil yang baik karena koefisien Cronbach Alpha yang dihasilkan telah memenuhi rules of thumb yang direkomendasikan (Hair et. al., 1998; Sekaran, 2000).

\section{Statistik Deskriptif dan Korelasi Antar- Konstruk}

Tabel 7 dan 8 menunjukkan statistik deskriptif dan korelasi antar-konstruk.
Tabel 7 Statistik Deskriptif

\begin{tabular}{lccc}
\hline \multicolumn{1}{c}{ Konstruk } & \multicolumn{3}{c}{$\begin{array}{c}\text { St. } \\
\text { Deviation }\end{array}$} \\
\hline Functional Quality (FQ) & 3.586 & 0.831 & 239 \\
Technical Quality (TQ) & 3.520 & 0.846 & 239 \\
Corporate Image (CI) & 3.586 & 0.808 & 239 \\
Customer Satisfaction (CS) & 3.476 & 0.883 & 239 \\
\hline
\end{tabular}

Tabel 8 Korelasi Antar-Konstruk

\begin{tabular}{rcccc}
\hline Konstruk & TFQ & TTQ & TCI & TCS \\
\hline TFQ Pearson Correlation & 1 & $0.740^{* *}$ & $0.793^{* *}$ & $0.749^{* *}$ \\
Sig (2-tailed) &. & 0.0000 & 0.000 & 0.000 \\
$\mathrm{~N}$ & 239 & 239 & 239 & 239 \\
TTC Pearson Correlation & $0.740^{* *}$ & 1 & $0.7433^{* *}$ & $0.622^{* *}$ \\
Sig (2-tailed) & 0.000 &. & 0.000 & 0.000 \\
$\mathrm{~N}$ & 239 & 239 & 239 & 239 \\
TCI Pearson Correlation & $0.793^{* *}$ & $0.743^{* *}$ & 1 & $0.735^{* *}$ \\
Sig (2-tailed) & 0.000 & 0.000 &. & 0.000 \\
$\mathrm{~N}$ & 239 & 239 & 239 & 239 \\
TCS Pearson Correlation & $0.748^{* *}$ & $0.622^{* *}$ & $0.735^{* *}$ & 1 \\
Sig (2-tailed) & 0.000 & 0.000 & 0.000 &. \\
$\mathrm{~N}$ & 239 & 239 & 239 & 239 \\
\hline \multicolumn{5}{c}{ Correlation is significant at the 0.01 level (2-tailed). } \\
* Correlation is significant at the 0.05 level (2-tailed). \\
Sumber: Hasil Pengolahan Data
\end{tabular}

Tabel 7 secara umum dapat disimpulkan bahwa responden menilai functional quality, technical quality, corporate image, dan customer satisfaction yang relatif tinggi (mean > 3). Tabel 8 menunjukkan konstruk-konstruk penelitian yang memiliki korelasi signifikan, yaitu a) hubungan antara func-tional quality dengan technical quality, corporate image, dan customer satisfac-tion; b) hubungan antara technical quality dengan corporate image dan customer satisfaction; dan (c) hubungan antara corporate image dengan customer satisfaction.

\section{Metode Analisis data dan Pembahasan}

Metode analisis data yang digunakan dalam penelitian ini adalah regresi berganda (multiple regrresion). Pada penelitian ini terdapat tiga hipotesis. Hipotesis pertama adalah functional quality akan berpengaruh positif pada customer satisfaction. Hipotesis kedua adalah adalah technical quality akan berpengaruh positif pada customer satisfaction. Hipotesis ketiga adalah adalah corporate image akan berpengaruh positif pada customer satisfaction. 
Tabel 9 Model Summary

\begin{tabular}{ccccc}
\hline Model & $\mathbf{R}$ & $\begin{array}{c}\text { R } \\
\text { Square }\end{array}$ & $\begin{array}{c}\text { Adjusted } \\
\text { R Square }\end{array}$ & $\begin{array}{c}\text { Std. Error of } \\
\text { the Estimate }\end{array}$ \\
\hline 1 & $.784(\mathrm{a})$ & .614 & .609 & .55186
\end{tabular}

(a) Predictors: (Constant), TCI, TTQ, TFQ

Sumber: Hasil Pengolahan Data

Tabel 9 menunjukkan model summary yang mana nilai $\mathrm{R}$ sebesar 0,784 mengindikasikan adanya korelasi antara customer satisfaction dengan 3 (tiga) variabel prediktor cukup kuat. Nilai adjusted $R$ square sebesat 0,609 menunjukkan bahwa $60,9 \%$ variasi dari customer satisfaction bisa dijelaskan oleh variasi dari ketiga variabel prediktor (variabel independen), yaitu functional quality, technical quality, dan corporate image. Sedangkan 39,1\% dijelaskan oleh faktor-faktor lain.

Tabel 10 Koefisien Regresi

\begin{tabular}{|c|c|c|c|c|c|c|}
\hline \multirow[b]{2}{*}{ Model } & & \multicolumn{2}{|c|}{$\begin{array}{l}\text { Unstandardized } \\
\text { Coefficients }\end{array}$} & \multirow{2}{*}{$\begin{array}{c}\text { Standardized } \\
\text { Coefficients } \\
\text { Beta }\end{array}$} & \multirow[b]{2}{*}{$t$} & \multirow[b]{2}{*}{ Sig } \\
\hline & & B & Std. Error & & & \\
\hline \multirow[t]{4}{*}{1} & (Cons) & .270 & .172 & & 1.568 & .118 \\
\hline & TFQ & .464 & .076 & .437 & 6.113 & .000 \\
\hline & TTQ & .023 & .068 & .022 & .345 & .730 \\
\hline & $\mathrm{TCl}$ & .406 & .079 & .372 & 5.164 & .000 \\
\hline
\end{tabular}

Dependent Variable: TCS (Customer Satisfaction) Sumber: Hasil Pengolahan Data

Tabel 10 menunjukkan bahwa nilai beta di atas merupakan nilai koefisien regresi untuk data yang sudah dibakukan. Nilai tersebut merupakan nilai koefisien jalur. Seluruh variabel independen pada penelitian ini memiliki arah pengaruh yang sesuai dengan arah pengaruh yang dihipotesiskan.

Hasil uji hipotesis untuk pengaruh dari setiap variabel independen pada variabel dependen dilakukan dengan melihat nilai signifikansi t dengan $\alpha=0.05$. Berdasarkan pada tabel 10, functional quality (TFQ) berpengaruh positif dan signifikan pada customer satisfaction. Hasil ini mendukung hipotesis pertama $\left(\mathrm{H}_{1}\right)$. Penemuan ini mengkonfirmasi hasil penemuan penelitian yang dilakukan oleh Banwet dan Datta (2003), Kang dan James (2004), Serta Choi et al. (2004). Hasil ini menunjukkan bahwa kualitas fungsional sudah sesuai dengan ekspektasi mahasiswa. Hasil ini menunjukkan bahwa mahasiswa merasa senang dan puas dengan ruang kelas, area parkir, penampilan dosen dan karyawan, sarana dan pra-sarana, sistem administrasi yang cepat, kejelasan materi yang disampaikan, kemampuan dosen, kemudahan bertemu dengan dosen, keramahan, dan lainnya.

Technical quality (TTQ) tidak berpengaruh secara signifikan pada customer satisfaction. Dengan demikian, hipotesis kedua $\left(\mathrm{H}_{2}\right)$ ditolak. Penemuan ini berbeda dengan penelitianpenelitian sebelumnya. Kang dan James (2004) dan Banwet dan Datta (2003) menemukan bahwa technical quality berpengaruh positif signifikan pada kepuasan pelanggan. Hasil temuan pada penelitian ini mungkin disebabkan karena responden (mahasiswa/i) sulit untuk mengevaluasi secara cepat kompetensi dosen dan karyawan. Hal ini disebabkan karena kurangnya kemampuan pelanggan (mahasiswa/i) dalam menilai aspek teknis kualitas layanan. Sebagai contoh mahasiswa sulit untuk menilai kedalaman dosen dalam memahami materi yang disampaikan dan mahasiswa sulit untuk menilai diri sendiri atas pemahaman mereka terhadap materi yang disampaikan.

Hasil temuan lainnya menunjukkan bahwa corporate image (TCI) berpengaruh positif dan signifikan pada customer satisfaction. Dengan demikian, hipotesis ketiga $\left(\mathrm{H}_{3}\right)$ diterima. Penemuan ini mengkonfirmasi penelitian dari Andreassen dan Lindestad (1998) yang mana corporate image berpengaruh positif signifikan pada kepuasan pelanggan. Hasil ini menunjukkan bahwa Universitas Kristen Maranatha memiliki reputasi baik, dapat dipercaya, universitas yang berkualitas, dan juga banyak memberikan kontribusi bagi masyarakta melalui kegiatankegiatan pengabdian masyarakat yang dilakukan oleh dosen.

\section{KESIMPULAN DAN SARAN}

Berdasarkan hasil analisis dan pembahasan sebelumnya, dapat diambil beberapa kesimpulan yang menjadi jawaban atas tujuan penelitian yang telah ditetapkan.

1. Kualitas fungsional (functional quality) berpengaruh positif pada kepuasan pelanggan. Hasil ini mengkonfirmasi studi-studi sebelumnya (Banwet \& Datta, 2003; Kang \& James, 2004; Choi et al., 2004).

2. Kualitas teknis (tehnical quality) tidak berpengaruh pada kepuasan pelanggan. Berbeda dengan studi-studi sebelumnya (Kang \& James, 2004; Banwet \& Datta, 
2003). Hasil temuan pada penelitian ini mungkin disebabkan karena sulitnya responden (mahasiswa/i) dalam menilai secara cepat kualitas teknik penyedia jasa. Hal ini disebabkan karena kurangnya kemampuan pelanggan (mahasiswa/i) dalam menilai aspek teknis kualitas layanan (Kang \& James, 2004).

3. Citra korporat (corporate image) berpengaruh positif signifikan pada kepuasan pelanggan. Hasil temuan pada penelitian ini mengkonfimasi studi yang dilakukan oleh Andreassen dan Lindestad (1998) yang mana citra korporat berpengaruh positif signifikan pada kepuasan pelanggan.

\section{Keterbatasan, Saran Bagi Penelitian Mendatang, dan Saran Bagi UKM}

Responden pada penelitian ini hanya memfokuskan pada mahasiswa/i jurusan Manajemen Fakultas Ekonomi UKM. Hal ini akan memengaruhi tingkat generalisasi hasil penelitian dalam setting lain. Objek penilaian kualitas layanan tidak spesifik.

Penelitian akan datang sebaiknya tidak memfokuskan pada satu jurusan atau satu Universitas dan menguji variabel-variabel pada penelitian ini dalam setting yang berbeda. Penelitian akan datang diharapkan dapat memfokuskan pada objek penilaian kualitas layanan yang lebih spesifik, misalnya fokus pada bidang akademik atau bidang non-akademik.

Saran bagi institusi Universitas Kristen Maranatha selaku pelaku industri jasa dalam konteks penelitian ini, yaitu perlu peningkatan kualitas layanan baik secara teknis maupun fungsional. Mahasiswa harus mendapatkan perlakuan yang ramah dan adil, pengetahuan setelah mengikuti kuliah, materi dan buku-buku referensi, penilaian kinerja secara objektif, kondisi dan peralatan yang memadai dalam membantu proses pembelajaran. Dimensi lain dalam kualitas layanan adalah citra korporat (citra Universitas Kristen Maranatha/UKM). Citra korporat merupakan hasil dari bagaimana pelanggan memersepsikan perusahaan - dalam konteks penelitian ini citra korporat berarti bagaimana mahasiswa memersepsikan UKM. Citra dapat dibangun melalui konsistensi dalam menyampaikan kualitas layanan baik teknis maupun fungsional. Faktor lain yang dapat dilakukan adalah melalui integrated marketing communication.

\section{DAFTAR PUSTAKA}

Andreassen, T. W. \& Lindestad, B. (1998). Customer Loyalty and Complex Services: The Impact of Corporate Image on Quality, Customer Satisfaction, and Loyalty for Customers with Varying Degrees of Service Expertise. International Journal of Service Industry Management, 9 (1): 7 23.

Banwet, D. K. \& Datta, B. (2003). A Study of the Effect of Perceived Lecture Quality on Post-Lecture Intentions. Work Study, 52 (5): 234-243.

Berry, L. L., Zeithaml, V. A., Parasuraman, A. (1985). Quality Comes in Services, too. Business Horizon, 28: 44-52.

Brady, M. K. \& Cronin, J. J.Jr. (2001). Some New Thoughts on Conceptualizing Perceived Servive Quality: A Hierarchical Approach. Journal of Marketing, 65 (July): 34-49.

Choi, K., Cho, W., Lee, S., Lee, H. \& Kim, C. (2004). The Relatonship among Quality, Value, and Satisfaction and Behavioral Intention in Health Care Provider Choice: A South Korean Study. Journal of Business Research, 57: 913-921.

Ganesh, R. \& Haslinda, A. (2014). Evolution and Conceptual Development of Service Quality in Service Marketing and Customer Satisfaction. International Review of Management and Business Research, 3 (2): 1189-1197.

Giantari, I. G. A. K., Widagda, I. G. N. J. A., Ardhani, I. G. A. K. S., \& Rahanatha, G. B. (2008). Analisis Kepuasan Mahasiswa terhadap Proses Belajar Mengajar di Program Diploma III FE UNUD. Buletin Studi Ekonomi, 13 (1): 52-66.

Grönroos, C. (1984a). An Applied Service Marketing Theory. European Journal of Marketing, 16 (7): 30-41.

Grönroos, C. (1984b). A Service Quality Model and Its Marketing Implications. European Journal of Marketing, 18 (4): 36-44.

Hair, J. R., Anderson, R. E., Tatham, R. L., \& Black, W. C. (1998). Multivariate Data Analysis. $5^{\text {th }}$ ed. Upper Saddle River, NJ: Prentice-Hall, Inc.

Kang, G. (2006). The Hierarchical of Service Quality: Integration of Technical and 
Functional Quality. Managing Service Quality, 16 (1): 37-50.

Kang, G. \& James, J. (2004). Service Quality Dimensions: An Examination of Grönroos's Service Quality Model. Managing Service Quality, 14 (4): 266277.

Kotler, P. \& Keller, K. (2012). Marketing Management (14th ed.). Upper Saddle River, NJ: Prentice Hall

Lagrosen, S., Seyyed-Hashemi, R., \& Leitner, M. (2004). Examination of the Dimensions of Quality in Higher Education. Quality Assurance in Education, 12 (2): 61-69.

Lovelock, C., \& Wirtz, J. (2007). Service Marketing: People, Technology \& Strategy. (6th Ed.). USA, Prentice Hall, Inc.

Parasuraman, A., Zeithaml, V. A., \& Berry, L. L. (1985). A Conceptual Model of Service Quality and its Implications for Future Research. Journal of Marketing, 49 (Fall): 41-50.

Parasuraman, A., Zeithaml, V. A., \& Berry, L. L. (1988). SERVQUAL: A Multiple-Item Scale for Measuring Consumer Perceptions of Service Quality. Journal of Retailing, 64 (1): 12-40.

Rahman, M. S., Khan, A. H., \& Haque, M. M. (2012). A Conceptual Study on the Relationship between Service Quality towards Customer Satisfaction: Servqual and Gronroos's Service Quality Model Perspective. Asian Social Science, 8 (13): 201-210.

Swartz, T. A. \& Brown, S. W. (1989). Consumer and Provider Expectations and Experiences Evaluating Professional Service Quality. Journal of the Academy of Marketing Science, 17 (2): 189-195.

Vatta, S., \& Bhatara, M. (2013). Quality Of Service And Satisfaction Among Students In Private Higher Education Institutes In India. Golden Research Thoughts, 2 (9), 1-7. 